\title{
Spatio-temporal variation in diet may affect condition and abundance of juvenile European hake in the Gulf of Lions (NW Mediterranean)
}

\author{
Franck Ferraton $^{1,2, *}$, Mireille Harmelin-Vivien ${ }^{2}$, Capucine Mellon-Duval $^{1}$, \\ Arnaud Souplet ${ }^{1}$
}

\footnotetext{
${ }^{1}$ Centre de Recherche Halieutique Méditerranéenne et Tropicale, IFREMER, Laboratoire Ressources Halieutiques, Avenue Jean Monnet, BP 171, 34203 Sète Cedex, France

${ }^{2}$ Centre d'Océanologie de Marseille, Université de la Méditerranée, CNRS UMR 6540, Station Marine d'Endoume, rue Batterie des Lions, 13007 Marseille, France
}

\begin{abstract}
Variations in space and time of juvenile hake diet (5 to $19 \mathrm{~cm}$ total length, TL) were investigated in the Gulf of Lions (NW Mediterranean) and related to variation in C and N stable isotope ratios, condition and abundance. Crustaceans (mysids and euphausiids) dominated the diet of the smallest juvenile hake (5 to $9 \mathrm{~cm} \mathrm{TL}$ ), and fishes (sardines and anchovies) of the largest juveniles (15 to $19 \mathrm{~cm}$ TL). The transition from a crustacean- to a fish-based diet occurred in medium-sized juveniles (10 to $14 \mathrm{~cm}$ TL), which preyed on both crustaceans and fishes (gobiids). These juveniles preyed on fishes when living in shallow waters (30 to $50 \mathrm{~m})$, and crustaceans when located in deep waters $(70$ to $150 \mathrm{~m})$. Although hake diet did not change over time in shallow waters (fish-based diet), in deep waters it was dominated by mysids and euphausiids in 2002 and natantids in 2003. In the size range analysed, no correlation was found between juvenile hake length and their $\delta^{13} \mathrm{C}$ and $\delta^{15} \mathrm{~N}$ values, but a significant correlation with depth was observed, with higher values in shallow waters. The condition factor of medium-sized juveniles did not vary with depth in 2002, but was significantly lower in deep waters in 2003 when they fed on natantids instead of small crustaceans. Abundance of juvenile hake in the Gulf of Lions drastically decreased from 2002 to 2003, particularly in deep waters. The lower condition factor of juvenile hake in deep waters in 2003, probably owing to a lack of suitable food, might have negatively affected their survival. These results support the hypothesis that food resources influence condition and survival of juvenile hake when settled, and thus affect NW Mediterranean fisheries.
\end{abstract}

KEY WORDS: Merluccius merluccius · Stomach contents · Stable isotopes · Carbon · Nitrogen · Relative condition factor $\cdot$ Recruitment

\section{INTRODUCTION}

The European hake Merluccius merluccius (Linnaeus, 1758) is widely distributed in the Mediterranean from shallow waters $(30 \mathrm{~m})$ down to a depth of $800 \mathrm{~m}$, with juveniles mainly concentrated on the continental shelf (50 to $200 \mathrm{~m}$ ) and adults deeper on the slope and canyons (Abella et al. 1997, Orsi-Relini et al. 2002, Maynou et al. 2003). It is the most important commercial fish species in the demersal fisheries of the
Gulf of Lions (NW Mediterranean) in term of landings (Aldebert et al. 1993), and is caught mainly by bottom trawlers that operate over the continental shelf and upper slope (Aldebert et al. 1993, Recasens et al. 1998). As a consequence of the size distribution of this species with depth and the small mesh size of gear used (45 mm stretched), such fisheries rely mostly on juveniles, with an individual median size of 12 to $14 \mathrm{~cm}$ total length (TL) in trawl landings (Abella et al. 1997, Recasens et al. 1998, Orsi-Relini et al. 2002, Goñi et al. 
2004). It is thus of prime importance to obtain information on the different factors likely to influence the fluctuations in abundance of juvenile hake.

Hake recruitment occurs all year round in the NW Mediterranean, with some seasonal peaks and large interannual fluctuations, and juveniles of different sizes are found in all seasons on the continental shelf (Recasens et al. 1998, Lloret \& Lleonart 2002, Maynou et al. 2003, Goñi et al. 2004). Factors acting at large spatial scales, such as environmental factors and primary productivity, can influence the success of reproduction and larval stages (Lloret et al. 2001, Olivar et al. 2003). After benthic settlement, other factors such as habitat quality, food supply, intra- and inter-specific competition may influence growth, condition and survival of juvenile hake (Lloret et al. 2002, Maynou et al. 2003).

Knowledge of the diet composition of fishes and their adaptability to food resource fluctuations is of major importance to the understanding of fluctuations in fish abundance. Diet of hake was described by numerous authors researching this species in the Atlantic (Guichet 1995, Du Buit 1996, Velasco \& Olaso 1998, Pinnegar et al. 2003), the Mediterranean (Papaconstantinou \& Caragitsou 1987, Cartes et al. 2004) and in particular the Gulf of Lions (Bozzano et al. 1997, 2005). These authors demonstrated that hake diet changes with size, being mainly crustacean-based in juveniles and fish-based in adults. However, ontogenetic variations in hake diet have, to date, only been assessed at large spatial scales and using, at best, $10 \mathrm{~cm}$ size classes.

In the present study, we focused on fluctuations in the diet of juvenile hake ( 5 to $19 \mathrm{~cm}$ TL) over space and time in the Gulf of Lions, and investigated relationships with hake condition and abundance. The analysis of diet composition was conducted using $5 \mathrm{~cm}$ size classes, which provided accurate information on ontogenic changes; furthermore, variability was assessed at a fine spatial scale. Feeding was examined using 2 methods - stomach contents and stable isotopes analysis - that provided complementary information on trophic ecology. Dietary indices, calculated from stomach contents, allow the identification and determination of the relative importance of prey recently ingested by the predator. In contrast, stable isotope composition of muscle integrates all food types assimilated by the fish over the several months that precede sampling (Hesslein et al. 1993, MacAvoy et al. 2001). The carbon isotope signature $\left(\delta^{13} \mathrm{C}\right)$ can be used to identify organic sources at the base of food webs, because $\delta^{13} \mathrm{C}$ increases weakly from prey to predator by an average of $1 \%$ (De Niro \& Epstein 1978, Pinnegar \& Polunin 1999, Vander Zanden \& Rasmussen 2001), and primary producers have distinct $\delta^{13} \mathrm{C}$ values. In the case of nitrogen $\left(\delta^{15} \mathrm{~N}\right)$, a mean fractionation of $3.4 \%$ is observed during trophic transfer, which allows the definition of an organism's trophic level (De Niro \& Epstein 1981, Minagawa \& Wada 1984, Vander Zanden \& Rasmussen 2001). Thus, combined measurements of stable isotope ratios of carbon and nitrogen are currently used in the analysis of marine food web structure (Minagawa \& Wada 1984, Vander Zanden \& Rasmussen 2001). Condition indices are used as simple indicators of the wellbeing and nutritional status of fish (Lambert \& Dutil 1997, Lloret et al. 2002).

The main aims of the present study were to (1) examine how juvenile hake diet varies with size, space and time, (2) examine how the $\mathrm{C}$ and $\mathrm{N}$ isotope signatures of juvenile hake change with these parameters, and (3) explore whether the condition and abundance of juvenile hake are related to differences in diet.

\section{MATERIALS AND METHODS}

Study area and sampling. Sampling was conducted in the Gulf of Lions (NW Mediterranean), from the Rhone River delta to Cape Béar (Fig. 1). Juvenile hake were collected in 2002 and 2003 by diurnal standardised trawling performed during the annual European MEDITS (International bottom trawl survey in the Mediterranean Sea) survey on the shelf and continental slope of the western Mediterranean (Orsi-Relini et al. 2002). The survey takes place each year in the Gulf of Lions in June (during spring), which is the season of highest juvenile hake abundance (Recasens et al. 1998). The bottom trawl used was the GOC 73 constructed with 2 panels on the sides, with a footrope of $28.2 \mathrm{~m}$, and $20 \mathrm{~mm}$ stretched meshes in the cod-end. The wingspread of the trawl was measured for each haul (mean of 94 hauls conducted $=17.8 \mathrm{~m}$ ) by navigation acoustic devices (SCANMAR) once the trawl was stabilised. Hauls lasted 60 min at a speed of 3 knots, and were performed from $07: 00 \mathrm{~h}$ to 19:00 $\mathrm{h}$ on about $20 \mathrm{~d}$ of each year. Overall, 53 hauls out of a total of 94 hauls conducted in 2002 and 2003 were used for studying spatial and interannual differences in hake diet, based on the presence of juvenile hake at the same locations in both years. Hauls were selected from 4 zones (Fig. 1) on the continental shelf from east (Zone 1) to west (Zone 4). Two depth ranges were identified in each zone: shallow (30 to $50 \mathrm{~m}$ ) and deep (70 to $150 \mathrm{~m}$ ). Note that no hauls were conducted in the 50 to $70 \mathrm{~m}$ depth range.

Stomach content analysis. Stomach contents of 1283 juvenile hake from 5.0 to $19.9 \mathrm{~cm}$ TL were analysed in 2002, whereas stomachs from only 462 individuals were examined in 2003 due to the lower abundance of juvenile hake. Stomach contents were removed and fixed in $5 \%$ buffered formalin. Each prey was identi- 


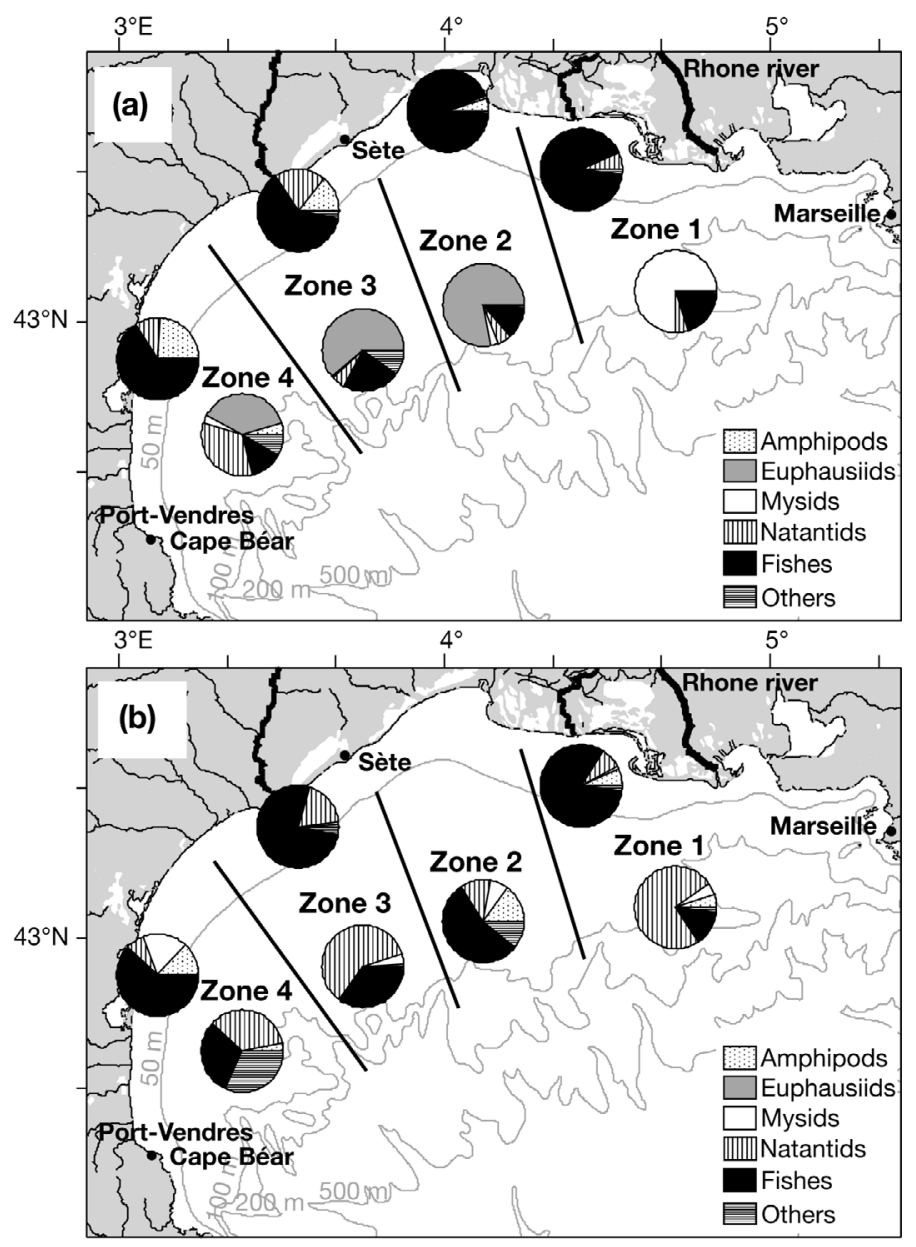

Fig. 1. Merluccius merluccius. Spatial and annual variability in diet composition (\% IRI) of juveniles of 10 to $14 \mathrm{~cm}$ TL sampled in (a) 2002 and (b) 2003. No. of stomachs containing food in 2002 and 2003 is 454 and 133, respectively. (One area not shown in 2003 because of small sample size, $n=3$ )

fied to the lowest taxonomic level possible depending on digestion state, counted individually and weighed (dry weight to the nearest $0.01 \mathrm{mg}$ recorded after $24 \mathrm{~h}$ oven drying at $60^{\circ} \mathrm{C}$ ), grouped according to broad taxonomic categories. Feeding was described using 3 dietary indices: \% frequency occurrence ( $\% F O)$, \% by number $(\% N)$ and $\%$ by weight $(\% W)$, defined as follows (Hyslop 1980):

$\% F O=\frac{\text { no. stomachs containing } 1 \text { prey category }}{\text { no. stomachs containing food }} \times 100$

$\% N=\frac{\text { no. individuals of } 1 \text { prey category }}{\text { total no. of prey of all categories }} \times 100$

$\% W=\frac{\text { dry wt of } 1 \text { prey category }}{\text { total dry wt of prey of all categories }} \times 100$

The contribution of each prey category to the diet was quantified using the index of relative importance
(\%IRI), which takes into account the 3 previous indices and was expressed as (Pinkas et al. 1971):

$$
\% \text { IRI }=\frac{\text { IRI }}{\sum_{a=1}^{\mathrm{n}} \mathrm{IRI}} \times 100
$$

where IRI $=\% F O \times(\% N+\% W)$ and $\mathrm{n}$ is the number of different prey categories (a).

To analyse ontogenic changes in diet composition, juvenile hake were grouped by $5 \mathrm{~cm}$ (TL) length class. As individuals of 10 to $14 \mathrm{~cm}$ TL presented the most diverse diet and were the most numerous in our samples (see Table 1), this size class was used to study the spatio-temporal variations in juvenile hake feeding in the Gulf of Lions according to depth, location and year.

Stable isotope analysis. The ${ }^{13} \mathrm{C}:{ }^{12} \mathrm{C}$ and ${ }^{15} \mathrm{~N}:{ }^{14} \mathrm{~N}$ ratios of juvenile hake were analysed on dorsal white muscle, because this tissue gives the most reliable results with the lowest variability among individuals (Pinnegar \& Polunin 1999). Muscle samples were individually frozen at $-20^{\circ} \mathrm{C}$ before freeze-drying. Dried samples were ground into a fine and homogeneous powder using a mortar and pestle, and $1 \mathrm{mg}$ was weighed in tin capsules for isotopic analysis. The ${ }^{13} \mathrm{C}:{ }^{12} \mathrm{C}$ and ${ }^{15} \mathrm{~N}:{ }^{14} \mathrm{~N}$ ratios were analysed by continuous-flow isotope-ratio mass spectrometry. The spectrometer (Europa Scientific ANCA-NT 20-20 stable isotope analyser with ANCA-NT solid/liquid preparation module) was operated in the dual isotope mode, allowing ${ }^{15} \mathrm{~N}:{ }^{14} \mathrm{~N}$ and ${ }^{13} \mathrm{C}:{ }^{12} \mathrm{C}$ ratios to be measured simultaneously on the same sample. The analytical precision $(\mathrm{SD}, \mathrm{n}=5$ ) was $0.2 \%$ for both $\mathrm{N}$ and $\mathrm{C}$, estimated from standards analysed along with the samples. Internal working standards were $1 \mathrm{mg}$ leucine, prepared by freeze drying $50 \mu \mathrm{l}$ of a $20 \mathrm{mg} \mathrm{ml}^{-1}$ stock solution into tin capsules, and calibrated against 'Europa flour' and International Atomic Energy Agency (IAEA) standards $\mathrm{N} 1$ and N2. The following $\delta$ notation was used:

$$
\delta X(\%)=\left[\frac{R_{\text {sample }}}{R_{\text {standard }}}-1\right] \times 10^{3}
$$

where $X$ is ${ }^{13} \mathrm{C}$ or ${ }^{15} \mathrm{~N}$ and $R$ the corresponding ratio of ${ }^{13} \mathrm{C}:{ }^{12} \mathrm{C}$ or ${ }^{15} \mathrm{~N}:{ }^{14} \mathrm{~N}$.

The standard reference materials were Vienna Pee Dee Belemnite (VPDB) for carbon and atmospheric $\mathrm{N}_{2}$ for nitrogen.

Linear regression was used to identify relationships between $\delta^{13} \mathrm{C}$ and $\delta^{15} \mathrm{~N}$ and fish size. The effects of year, zone and depth were analysed by 3-way ANOVA after testing and accepting the normality of data (Kolmogorov-Smirnov test) and homogeneity of variance (Bartlett's test). A 2-way ANOVA was used to test the effects of zone and depth each year, and post-hoc comparisons of means were performed using Tukey's test. The spatio-temporal variations in stable isotope 
signatures of juvenile hake were analysed for the medium size class ( 10 to $14 \mathrm{~cm}$ TL), because these fish were present and numerous enough at all locations.

Condition factor. To study the variation in juvenile hake condition with depth and year while avoiding the effect of length, the relative condition factor $K_{\mathrm{n}}$ was used (Le Cren 1951). For each specimen, TL (in cm) and eviscerated weight $\left(W e\right.$, in $g$ ) were recorded. $K_{\mathrm{n}}$ was computed with the formula:

$$
K_{\mathrm{n}}=\frac{W e}{W e^{\prime}}
$$

where $W e$ is the observed individual eviscerated weight and $W e^{\prime}$ is the estimated eviscerated weight from the $\log _{10} W e-\log _{10}$ TL relationship (We' $=10^{- \text {intercept }}$ $\times \mathrm{TL}^{\text {slope }}$ ).

After examining and accepting the normality of data (Kolmogorov-Smirnov test) and homogeneity of variance (Bartlett test), a 3-way ANOVA was used to analyse the effects of year, depth and zone on condition factor of juvenile hake. Tukey's test was performed for post-hoc comparisons of means.

Density. Density was computed from the MEDITS data collected from the 94 hauls conducted during 2002 and 2003. Abundance indices by length class (no. of ind. $\mathrm{km}^{-2}$ ) were calculated for each haul (Cochran 1977) as:

$$
A_{i}=\frac{X_{i}}{C S_{i}}
$$

where $C S_{i}=W_{i} \times S_{i} \times D_{i}$ and $A_{i}$ is abundance in haul $i$, $X_{i}$ is the sum of individuals in haul $i$ by length class,
$C S_{i}$ is the surface covered during haul $i, W_{i}$ is the measured wingspread of haul $i, S_{i}$ is the speed during haul $i$, and $D_{i}$ is the duration of haul $i$.

Mean density $( \pm \mathrm{SE})$ was then expressed for each location (zone $\times$ depth) and year:

$$
\bar{A}_{j}=\frac{\sum_{i=1}^{n_{j}} A_{i}}{n_{j}}
$$

where $\bar{A}_{j}$ is mean abundance at location $j$ by length class and year, and $n_{j}$ is the number of hauls at location $j$.

Densities were log-transformed to normalize data and stabilize variances, and a 3-way ANOVA was used to identify the effect of year, zone and depth on density.

\section{RESULTS}

\section{Ontogenetic variation in diet}

Variation in diet with size was evident among juvenile hake in the Gulf of Lions (Table 1). The smallest juveniles (5 to $9 \mathrm{~cm}$ TL) relied mostly on small crustaceans for food (\%IRI = 99). Among crustaceans, their main prey were euphausiids (Meganictiphanes norvegica [M. Sars, 1857]) $(\% \mathrm{IRI}=53)$ and mysids (Leptomysis spp., Syriella spp. Lophogaster spp.) (\%IRI = 33). The other crustaceans frequently caught by this size class were natantid decapods (Philocheras spp.,

Table 1. Merluccius merluccius. Diet composition related to size (total length, TL; $\mathrm{cm}$ ). Dietary indices used: \% frequency occurrence $(\% F O)$, \% by number $(\% N)$, \% by dry weight $(\% W)$ and $\%$ index of relative importance $(\%$ IRI) of each prey category. Benthic fishes: Gobiidae (Lesueurigobius friesii, Deltentosteus quadrimaculatus and Gobius niger), Callionymidae, Trachiuridae, Congridae and Triglidae; demersal fishes: Merluccius merluccius, Trisopterus minutus (Linnaeus, 1758) and Cepola macroph-

\begin{tabular}{|c|c|c|c|c|c|c|c|c|c|c|c|c|}
\hline \multirow[t]{2}{*}{ Total length: } & \multicolumn{4}{|c|}{$-5-9 \mathrm{~cm}-$} & \multicolumn{4}{|c|}{$-10-14 \mathrm{~cm}-$} & \multicolumn{4}{|c|}{$-15-19 \mathrm{~cm}$} \\
\hline & $\% F O$ & $\% N$ & $\% W$ & $\%$ IRI & $\% F O$ & $\% N$ & $\% W$ & $\%$ IRI & $\% F O$ & $\% N$ & $\% W$ & $\%$ IRI \\
\hline Crustaceans & 95.2 & 99.2 & 78.3 & 99.4 & 79.3 & 94.9 & 11.9 & 78.4 & 33.3 & 43.8 & 1.4 & 7.9 \\
\hline Amphipods & 14.2 & 2.9 & 1.7 & 1.1 & 16.8 & 4.3 & 0.1 & 2.3 & 7.4 & 6.3 & $*$ & 0.9 \\
\hline Euphausiids & 37.3 & 64.3 & 22.3 & 52.6 & 13.4 & 42.8 & 1.1 & 17.9 & 1.5 & 6.0 & * & 0.2 \\
\hline Mysids & 38.7 & 24.0 & 28.5 & 33.2 & 36.6 & 32.0 & 2.5 & 38.5 & 8.4 & 13.6 & 0.1 & 2.2 \\
\hline Isopods & 0.5 & 0.1 & * & * & 0.3 & 0.1 & * & * & 1.0 & 0.6 & * & * \\
\hline Cumaceans & 1.0 & 0.3 & 0.1 & * & 0.2 & * & * & * & - & - & _- & - \\
\hline Natantids & 25.0 & 3.9 & 18.1 & 9.0 & 33.7 & 7.6 & 7.1 & 15.2 & 15.3 & 11.7 & 1.1 & 3.7 \\
\hline Macrurans & - & - & - & - & 0.5 & 0.1 & 0.1 & ${ }^{*}$ & - & - & - & - \\
\hline Unidentified crustaceans & 18.6 & 3.7 & 7.7 & 3.5 & 16.3 & 8.0 & 1.0 & 4.4 & 7.9 & 5.7 & 0.2 & 0.9 \\
\hline Fishes & 4.5 & 0.7 & 21.1 & 0.6 & 19.5 & 4.7 & 85.9 & 21.5 & 64.3 & 53.9 & 97.7 & 92.0 \\
\hline Benthic fishes & 2.0 & 0.2 & 12.2 & 0.4 & 8.7 & 1.5 & 19.4 & 5.2 & 7.4 & 5.0 & 5.5 & 1.5 \\
\hline Demersal fishes & - & - & - & - & 1.6 & 0.3 & 6.7 & 0.3 & 2.0 & 1.3 & 5.0 & 0.2 \\
\hline Pelagic fishes & 0.5 & 0.1 & 7.0 & 0.1 & 1.6 & 0.3 & 35.9 & 1.8 & 16.3 & 10.7 & 57.2 & 21.1 \\
\hline Unidentified fishes & 3.9 & 0.4 & 1.9 & 0.1 & 17.4 & 2.7 & 23.9 & 14.1 & 54.2 & 36.9 & 30.0 & 69.2 \\
\hline Cephalopods & 0.3 & 0.1 & 0.6 & $*$ & 1.2 & 0.3 & 2.1 & 0.1 & 2.0 & 1.9 & 0.8 & 0.1 \\
\hline Polychaetes & - & - & - & - & - & - & - & - & 0.4 & 0.3 & $*$ & $*$ \\
\hline No. stomachs analysed & \multicolumn{4}{|c|}{296} & \multicolumn{4}{|c|}{1037} & \multicolumn{4}{|c|}{362} \\
\hline No. stomachs with food & \multicolumn{4}{|c|}{198} & \multicolumn{4}{|c|}{587} & \multicolumn{4}{|c|}{191} \\
\hline
\end{tabular}
thalma (Linnaeus, 1758); pelagic fishes: Sardina pilchardus, Engraulis encrasicolus and Micromesistius poutassou (Risso, 1827). Data from 2002 and 2003 combined. ${ }^{*}<0.1 \%$ 
Alpheus spp., Processa spp., Pontocaris spp.) (\%FO = 25) and amphipods (Westwoodilla spp.) (\%FO = 14). Fishes were rarely preyed by the smallest juvenile hake $(\% F O=4.5)$ and consisted mainly of small benthic species (gobiids).

Crustaceans remained the principal prey of mediumsized juvenile hake (10 to $14 \mathrm{~cm}$ TL) ( $\%$ IRI $=78 \%, \%$ FO $=79$ ) with mysids, natantids, amphipods and euphausiids being the most frequent prey. Fishes represented secondary prey for hake of 10 to $14 \mathrm{~cm}$ TL $(\%$ IRI = 21) and consisted mainly of gobiids (Lesueurigobius friesii [Malm, 1874], Deltentosteus quadrimaculatus [Valenciennes, 1837], Gobius niger Linnaeus, 1758). They were the most important prey in terms of weight (86\%) but were not frequently consumed $(\% F O=20)$.

The largest juvenile hake (15 to $19 \mathrm{~cm}$ TL) preyed mainly on fishes (\%IRI = 92), which dominated in terms of frequency, abundance and weight (Table 1). Pelagic fishes, mainly sardine Sardina pilchardus (Walbaum, 1792) and anchovy Engraulis encrasicolus (Linnaeus, 1758), were the most important prey for the largest juvenile hake in the Gulf of Lions. Crustaceans (natantids and mysids) represented only a small amount of prey consumed by this size class ( $\% W=1.4)$.

Other invertebrates, such as small cephalopods (Sepia spp., Sepiola spp., Allotheuthis spp.) and polychaetes, were uncommon as prey for juvenile hake irrespective of size. Thus, the smallest juvenile hake preyed mainly on crustaceans, and the largest hake on fishes. The medium sized juveniles (10 to $14 \mathrm{~cm}$ TL) had the most diverse diet, with crustaceans and fishes both being important prey.

\section{Spatio-temporal variation in diet}

The diet of medium-sized juvenile hake (10 to $14 \mathrm{~cm}$ TL) exhibited spatial and temporal variations in the Gulf of Lions. In shallow waters (30 to $50 \mathrm{~m}$ ), fishes were the main prey type for juvenile hake in most zones studied in 2002 (mean \%IRI = 78) as well as in 2003 (mean \%IRI = 66) (Fig. 1). In contrast, crustaceans dominated the diet of juvenile hake in deep waters (70 to $150 \mathrm{~m}$ ) in all zones in 2002 (mean \% IRI = 83) and 2003 (mean \%IRI = 67). However, the type of crustaceans ingested in deep waters differed among zones and between years (Fig. 1). In 2002, mysids dominated in the diet of juveniles located in Zone 1 (\%IRI = 75), whereas euphausiids were the dominant prey (mean \%IRI = 59) in Zones 2, 3 and 4. In 2003, no euphausiids were consumed by juvenile hake in any zone, and mysids were uncommon prey (mean \%IRI = 5). The most important crustacean prey in deep waters in 2003 were natantid decapods (mean $\% I R I=45$ ), followed to a lesser extent by amphipods (mean \%IRI = 8).

\section{Stable isotope signatures}

Stable isotope ratios of carbon and nitrogen in the muscle of juvenile hake were not correlated with body size in the size range analysed ( 5 to $19 \mathrm{~cm}$ TL) in either $2002\left(\delta^{13} \mathrm{C}: \mathrm{r}=-0.112, \mathrm{n}=174, \mathrm{p}=0.140 ; \delta^{15} \mathrm{~N}: \mathrm{r}=\right.$ $0.077, \mathrm{n}=174, \mathrm{p}=0.313)$ or $2003\left(\delta^{13} \mathrm{C}: \mathrm{r}=0.076, \mathrm{n}=98\right.$, $\left.\mathrm{p}=0.512 ; \delta^{15} \mathrm{~N}: \mathrm{r}=0.670, \mathrm{n}=98, \mathrm{p}=0.458\right)$. $\mathrm{C}$ and $\mathrm{N}$ ratios were significantly positively correlated $(\mathrm{r}=$ $0.700, \mathrm{n}=272, \mathrm{p}<0.001$ for both years), implying that juvenile hake with high $\delta^{13} \mathrm{C}$ also had high $\delta^{15} \mathrm{~N}$.

Isotopic signatures of hake 10 to $14 \mathrm{~cm}$ TL varied significantly with depth, year and zone (in decreasing order of importance) (Table 2). Juvenile hake had higher mean $( \pm \mathrm{SE}) \delta^{13} \mathrm{C}$ and $\delta^{15} \mathrm{~N}$ in shallow than deep water when both years were combined $\left(\delta^{13} \mathrm{C}_{\text {shallow }}=\right.$ $-17.64 \pm 0.08 \%$ vs. $\delta^{13} C_{\text {deep }}=-17.93 \pm 0.05 \%$; $\delta^{15} \mathrm{~N}_{\text {shallow }}=9.63 \pm 0.10 \%$ vs. $\delta^{15} \mathrm{~N}_{\text {deep }}=8.79 \pm 0.11 \%$ o); furthermore, mean $\delta^{13} \mathrm{C}$ and $\delta^{15} \mathrm{~N}$ were higher in 2002 than in $2003\left(\delta^{13} \mathrm{C}_{2002}=-17.67 \pm 0.05 \%\right.$ vs. $\delta^{13} \mathrm{C}_{2003}=$ $-18.07 \pm 0.05 \%$; $\delta^{15} \mathrm{~N}_{2002}=9.26 \pm 0.11 \%$ vs. $\delta^{15} \mathrm{~N}_{2003}=$ $8.89 \pm 0.11 \%$ o). In general, juvenile hake located in Zone 1, close to the Rhone river, exhibited significantly lower isotopic values $\left(\delta^{13} \mathrm{C}=-17.92 \pm 0.08 \%\right.$ and $\delta^{15} \mathrm{~N}$ $=8.74 \pm 0.12 \%)$ than those located in Zone $3\left(\delta^{13} \mathrm{C}=\right.$ $-17.68 \pm 0.08 \%$ and $\delta^{15} \mathrm{~N}=9.53 \pm 0.13 \%$ ); values of the other 2 zones were intermediate. The difference in isotopic signature with depth was significant in both years, but more pronounced in 2002 than in 2003 $\left(\Delta^{13} \mathrm{C}=0.43 \%\right.$ in 2002 vs. $0.21 \%$ in $2003 ; \Delta^{15} \mathrm{~N}=1.11 \%$ o in 2002 vs. $0.51 \%$ o in 2003) (Table 3). Mean $\delta^{13} \mathrm{C}$ and $\delta^{15} \mathrm{~N}$ were higher in shallow than in deep waters in 2002 as well as in 2003, except for $\delta^{13} \mathrm{C}$ in 2003 (Table 3). Differences in $\delta^{13} \mathrm{C}$ and $\delta^{15} \mathrm{~N}$ with depth were observed in the 4 zones studied in 2002, but the pattern

Table 2. Merluccius merluccius. Results of 3-way ANOVA of $\delta^{13} \mathrm{C}$ and $\delta^{15} \mathrm{~N}$ values of juvenile hake (10 to $14 \mathrm{~cm}$ TL) with effects of Year, Zone and Depth; ns: not significant

\begin{tabular}{|lcrcc|}
\hline & df & Mean SS & $F$ & $\mathrm{p}$ \\
\hline $\boldsymbol{\delta}^{\mathbf{1 3}} \mathbf{C}$ & & & & \\
Year & 1 & 4.243 & 37.850 & $<0.001$ \\
Zone & 3 & 0.402 & 3.590 & $<0.05$ \\
Depth & 1 & 2.798 & 24.960 & $<0.001$ \\
Year $\times$ Zone & 3 & 0.221 & 1.977 & $\mathrm{~ns}$ \\
Year $\times$ Depth & 1 & 0.175 & 1.561 & $\mathrm{~ns}$ \\
Zone $\times$ Depth & 3 & 0.450 & 4.015 & $<0.01$ \\
Year $\times$ Zone $\times$ Depth & 3 & 0.454 & 4.054 & $<0.01$ \\
$\boldsymbol{\delta}^{\mathbf{1 5}} \mathbf{N}$ & & 6.718 & 17.335 & $<0.001$ \\
Year & 1 & 2.616 & 6.751 & $<0.001$ \\
Zone & 3 & 16.064 & 41.447 & $<0.001$ \\
Depth & 1 & 0.144 & 0.371 & $\mathrm{~ns}$ \\
Year $\times$ Zone & 3 & 1.687 & 4.352 & $<0.05$ \\
Year $\times$ Depth & 1 & 1.005 & 2.594 & $\mathrm{~ns}$ \\
Zone $\times$ Depth & 3 & 0.862 & 2.234 & $\mathrm{~ns}$ \\
Year $\times$ Zone $\times$ Depth & 3 & & & \\
\hline
\end{tabular}


Table 3. Merluccius merluccius. Mean $( \pm \mathrm{SE}) \delta^{13} \mathrm{C}$ and $\delta^{15} \mathrm{~N}$ of medium-sized juvenile hake (10 to $14 \mathrm{~cm}$ TL) in the Gulf of Lions, for depth and zones in 2002 and 2003. Numbers in parentheses indicate sample size. Similar letters indicate means that are not significantly different $(p>0.05)$ for each respective factor. For zones see Fig. 1

\begin{tabular}{|c|c|c|c|c|c|c|c|c|}
\hline \multirow{3}{*}{ Depth } & \multirow{2}{*}{\multicolumn{4}{|c|}{-2002}} & \multirow{2}{*}{$\delta^{13} \mathrm{C}$} & \multirow[t]{2}{*}{2003} & \multirow{2}{*}{\multicolumn{2}{|c|}{$\delta^{15} \mathrm{~N}$}} \\
\hline & & & & & & & & \\
\hline & & & & & & & & \\
\hline $30-50 \mathrm{~m}$ & $-17.39 \pm 0.08(24)$ & $\mathrm{a}$ & $10.02 \pm 0.19(24)$ & a & $-17.96 \pm 0.10(19)$ & a & $9.15 \pm 0.14(19)$ & \\
\hline $70-150 \mathrm{~m}$ & $-17.82 \pm 0.05(44)$ & $\mathrm{b}$ & $8.91 \pm 0.09(44)$ & $\mathrm{b}$ & $-18.17 \pm 0.08(20)$ & $\mathrm{a}$ & $8.64 \pm 0.16(20)$ & $\mathrm{b}$ \\
\hline \multicolumn{9}{|l|}{ Zone } \\
\hline 1 & $-17.72 \pm 0.08(23)$ & $\mathrm{a}$ & $8.79 \pm 0.16(23)$ & $\mathrm{b}$ & $-18.34 \pm 0.32(11)$ & $\mathrm{b}$ & $8.63 \pm 0.19(11)$ & $\mathrm{a}$ \\
\hline 2 & $-17.74 \pm 0.11(15)$ & $\mathrm{a}$ & $9.09 \pm 0.28$ & ba & $-18.15 \pm 0.18(8)$ & b & $8.66 \pm 0.34(8)$ & $\mathrm{a}$ \\
\hline 3 & $-17.58 \pm 0.09(17)$ & $\mathrm{a}$ & $9.74 \pm 0.16(17)$ & $\mathrm{a}$ & $-17.85 \pm 0.14(10)$ & $\mathrm{a}$ & $9.20 \pm 0.21(10)$ & $\mathrm{a}$ \\
\hline 4 & $-17.61 \pm 0.12(13)$ & a & $9.68 \pm 0.23(13)$ & a & $-17.93 \pm 0.09(10)$ & $\mathrm{b}$ & $9.06 \pm 0.15(10)$ & $\mathrm{a}$ \\
\hline
\end{tabular}

was less obvious in 2003 (Fig. 2). The year $\times$ depth interaction showed that individuals from shallow waters had higher $\delta^{15} \mathrm{~N}$ content in 2002 than in 2003. Differences among zones were observed only for $\delta^{15} \mathrm{~N}$ in 2002 and $\delta^{13} \mathrm{C}$ in 2003, with lower values in Zone 1 and higher values in Zone 3 (Table 3). The significant depth $\times$ zone interaction for $\delta^{13} \mathrm{C}$ highlighted the difference between juveniles from shallow waters in Zone 3 with higher values and those from deep waters in Zones 1 \& 2 with lower values (Table 2, Fig. 2). In summary, the $\mathrm{C}$ and $\mathrm{N}$ isotope signatures of juvenile hake varied mainly with the depth of sampling and, to a lesser extent, with year and zone.

\section{Relationships between stable isotope ratios and diet}

No correlation was found between $\delta^{13} \mathrm{C}$ or $\delta^{15} \mathrm{~N}$ and $\%$ IRI, $\% N$ or $\% W$ at an individual level for any sample ( $p>0.05, n=272$ for all relationships tested). However, at a local population level (mean values of individuals grouped by location and year), a significant positive relationship existed between mean $\delta^{15} \mathrm{~N}$ and mean \%IRI of fishes in the diet of juvenile hake $(\mathrm{r}=0.530, \mathrm{n}=$ $16, p=0.017)$. The correlation between $\delta^{13} \mathrm{C}$ and \%IRI of fishes at a local population level was not significant $(\mathrm{r}=0.490, \mathrm{n}=16, \mathrm{p}=0.073)$. Mean $\delta^{13} \mathrm{C}$ and $\delta^{15} \mathrm{~N}$ were not correlated with mean $\% N$ or $\% W(\mathrm{p}>0.05, \mathrm{n}=16$, for all relationships tested). Juvenile hake located in shallow waters presented higher $\delta^{15} \mathrm{~N}$ values and had consumed more fish than juveniles located deeper on the continental shelf, both in 2002 (shallow: $\delta^{15} \mathrm{~N}=$ $10.02 \%$, $\%$ IRI $_{\text {fish }}=78 \%$; deep: $\delta^{15} \mathrm{~N}=8.86 \%$, $\% \mathrm{IRI}_{\text {fish }}=$ $17 \%$ ) and 2003 (shallow: $\delta^{15} \mathrm{~N}=9.15 \%$, \% IRI fish $=66 \%$; deep: $\delta^{15} \mathrm{~N}=8.64 \%$, $\% \mathrm{IRI}_{\text {fish }}=33 \%$ ).

\section{Condition factor}

Differences in the relative condition factor $K_{\mathrm{n}}$ of juvenile hake were observed with year (3-way

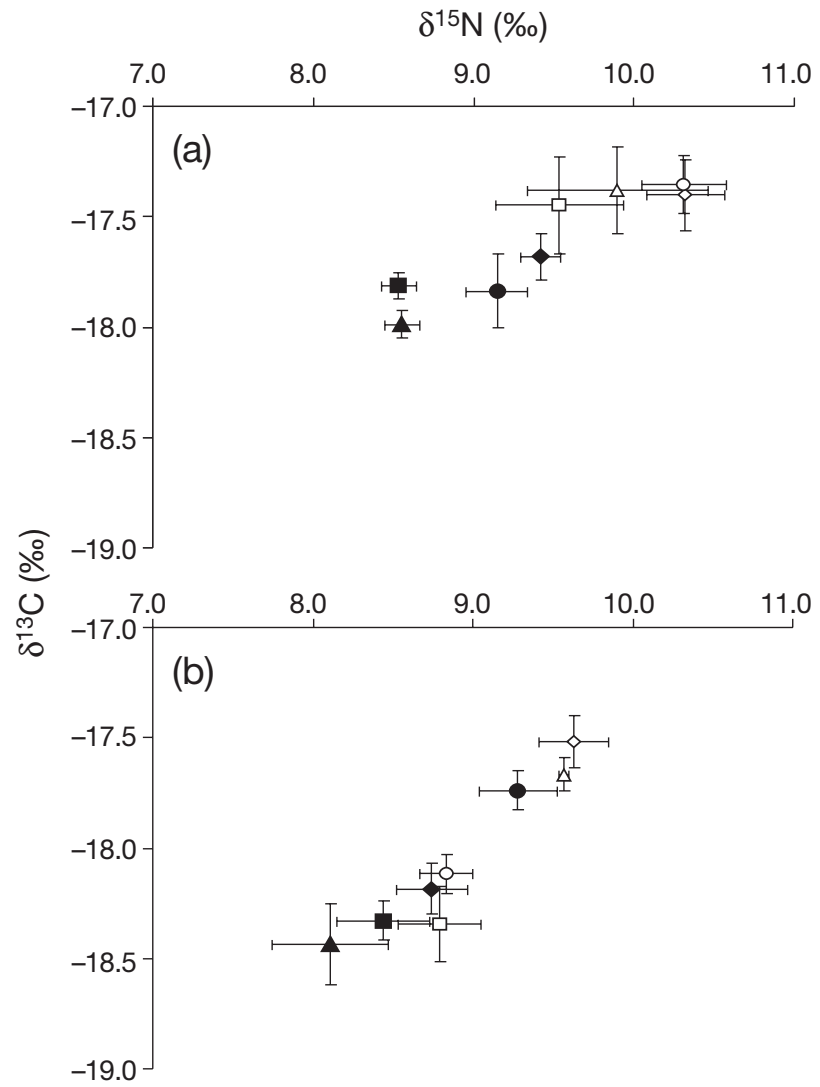

Fig. 2. Merluccius merluccius. Spatial variability in $\delta^{13} \mathrm{C}$ and $\delta^{15} \mathrm{~N}$ (mean $\pm \mathrm{SE}$ ) of juveniles of 10 to $14 \mathrm{~cm}$ TL sampled in (a) 2002 and (b) 2003. Squares: Zone 1; triangles: Zone 2; diamonds: Zone 3; circles: Zone 4. Empty and filled symbols represent $30-50 \mathrm{~m}$ and $70-150 \mathrm{~m}$ depth, respectively. No. of samples for each mean $=5$ to 12

ANOVA, $F=19.849, \mathrm{p}<0.001$ ) and depth (3-way ANOVA, $F=12.277, \mathrm{p}<0.001)$. No variation with zone was found (3-way ANOVA, $F=2.952$, p = 0.102). Juvenile hake had a mean condition $( \pm \mathrm{SE})$ that was higher in 2002 than in $2003\left(K_{\mathrm{n}}=1.02 \pm 0.01, K_{\mathrm{n}}=0.99 \pm 0.01\right.$, respectively) and higher in shallow than in deep waters $\left(K_{\mathrm{n}}=1.03 \pm 0.01, K_{\mathrm{n}}=0.99 \pm 0.01\right.$, respectively $)$. 
In 2002, no difference in mean $K_{\mathrm{n}}$ of juvenile hake with depth existed, whereas mean $K_{\mathrm{n}}$ was significantly lower at 70 to $150 \mathrm{~m}\left(K_{\mathrm{n}}=0.96 \pm 0.01\right)$ than at 30 to $50 \mathrm{~m}$ $\left(K_{\mathrm{n}}=1.04 \pm 0.01\right)$ for medium and largest juveniles in 2003 (Fig. 3). In the 70 to $150 \mathrm{~m}$ depth range, smallest and medium individuals showed significant lower condition in 2003 than in 2002 (1-way ANOVA, $F=21.199$, $\mathrm{p}<0.001$, and 1-way ANOVA, $F=14.977, \mathrm{p}<0.001$, respectively).

\section{Density of juvenile hake}

The density of juvenile hake in the Gulf of Lions varied both in space and time (Table 4). Year was the main factor of variation (3-way ANOVA, $F=31.063$, p < 0.001), with density of juvenile hake being higher in 2002 (mean $\pm \mathrm{SE}=1601 \pm 213$ ind $\mathrm{km}^{-2}$ ) than in 2003 $\left(242 \pm 23\right.$ ind $\left.\mathrm{km}^{-2}\right)$. Depth was the second factor of variation of juvenile hake density (in decreasing order of importance) (ANOVA, $F=4.417, \mathrm{p}=0.023$ ). A higher density of hake was found at 70 to $150 \mathrm{~m}$ $\left(1228 \pm 143\right.$ ind $\left.\mathrm{km}^{-2}\right)$ than at 30 to $50 \mathrm{~m}(616 \pm 111$ ind. $\left.\mathrm{km}^{-2}\right)$. No variation with zone was found $(F=0.236, \mathrm{p}=$ $0.104)$, nor was there any interaction between factors.

In both years, medium sized juveniles were more abundant than the smallest and largest juveniles (Table 4). In 2002 and 2003, the density of the smallest juveniles was higher in deep than in shallow waters in all 4 zones studied (Table 4 ). The density of mediumsized juveniles was higher in deep waters in all zones in 2002, but not in 2003. The largest juveniles displayed an opposite pattern, with a generally higher density in shallow waters in 2002 and 2003. The den-

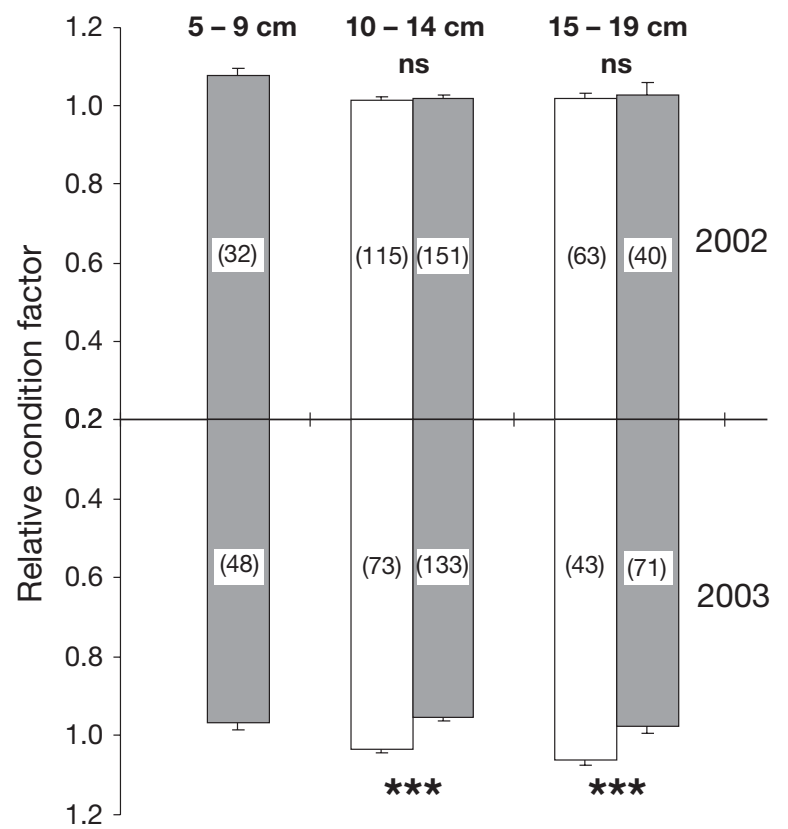

Fig. 3. Merluccius merluccius. Mean $( \pm \mathrm{SE})$ relative condition factor $K_{\mathrm{n}}$ of individuals grouped by length class (TL), year and depth strata. Empty and filled bars represent 30 to $50 \mathrm{~m}$ and 70 to $150 \mathrm{~m}$ depth, respectively. ***: significant differences with depth for each size group (Tukey's post-hoc test, p < 0.001); ns: not significant. Values in parentheses indicate sample size. (Condition of 5 to $9 \mathrm{~cm}$ TL hake in 30 to $50 \mathrm{~m}$ depth strata not shown because of small sample size, $\mathrm{n}=2$ )

sity of the 2 smallest size classes of juvenile hake was thus higher in deep waters, and the reverse was observed for the largest size class. Considerable interannual fluctuation in juvenile density was observed, with 6.6 times more juveniles in 2002 than in 2003.

Table 4. Merluccius merluccius. Mean density $( \pm \mathrm{SE})$ of individuals (ind. $\mathrm{km}^{-2}$ ) in 4 zones grouped by depth strata, length class and year. Values in bold $>2000$

\begin{tabular}{|c|c|c|c|c|c|c|}
\hline \multirow{3}{*}{ Zone 1} & \multirow{2}{*}{$5-9 \mathrm{~cm}$} & \multirow{2}{*}{$2002-14 \mathrm{~cm}$} & \multirow{2}{*}{$15-19 \mathrm{~cm}$} & \multirow{2}{*}{$5-9 \mathrm{~cm}$} & \multirow{2}{*}{$\begin{array}{l}-2003-14 \mathrm{~cm} \\
10-14\end{array}$} & \multirow[b]{2}{*}{$15-19 \mathrm{~cm}$} \\
\hline & & & & & & \\
\hline & & & & & & \\
\hline $30-50 \mathrm{~m}$ & 84 (13) & 1806 (411) & 1448 (315) & 91 & $618(220)$ & $273(68)$ \\
\hline $70-150 \mathrm{~m}$ & 2086 (1463) & 3025 (1229) & 654 (290) & $162(52)$ & 279 (109) & $140(65)$ \\
\hline \multicolumn{7}{|l|}{ Zone 2} \\
\hline $30-50 \mathrm{~m}$ & $286(60)$ & $1279(150)$ & 353 (123) & - & $56(32)$ & $255(32)$ \\
\hline $70-150 \mathrm{~m}$ & 4136 (1165) & 4192 (696) & 809 (482) & $298(66)$ & $305(44)$ & 168 (36) \\
\hline \multicolumn{7}{|l|}{ Zone 3} \\
\hline $30-50 \mathrm{~m}$ & 827 (171) & 3383 (648) & $513(185)$ & 22 & $455(47)$ & $336(62)$ \\
\hline $70-150 \mathrm{~m}$ & 3754 (1082) & 3862 (1157) & $122(41)$ & $183(43)$ & $370(50)$ & $156(41)$ \\
\hline \multicolumn{7}{|l|}{ Zone 4} \\
\hline $30-50 \mathrm{~m}$ & 327 (136) & 1419 (564) & $631(282)$ & 23 & 151 (87) & 140 (33) \\
\hline $70-150 \mathrm{~m}$ & $1184(352)$ & 2058 (405) & $193(42)$ & $141(29)$ & 854 (159) & $343(77)$ \\
\hline \multicolumn{7}{|l|}{ All zones } \\
\hline $30-50 \mathrm{~m}$ & 420 (109) & $1983(344)$ & 759 (169) & $45(23)$ & $338(80)$ & 249 (33) \\
\hline $70-150 \mathrm{~m}$ & $2862(528)$ & 3257 (442) & 362 (106) & 209 (29) & $463(61)$ & $211(30)$ \\
\hline
\end{tabular}


However, the between-year difference was higher for the smallest juveniles (14 times more abundant in 2002 than in 2003), which fed mainly on crustaceans, than for the largest juveniles (2.6 times more abundant in 2002 than in 2003), which preyed on fish.

Looking at the results of both condition and abundance, it appears that 10 to $14 \mathrm{~cm}$ hake were in similar condition in shallow and deep waters in 2002 (Fig. 3), whereas their abundance was higher in deep waters (Table 4: 3257 ind. $\mathrm{km}^{-2}$ vs. 1983 ind. $\mathrm{km}^{-2}$ ). In 2003, 10 to $14 \mathrm{~cm}$ hake were in better condition in shallow waters, with similar abundance in the 2 depth strata (Table 4: 338 ind. $\mathrm{km}^{-2}$ vs. 463 ind. $\mathrm{km}^{-2}$ in shallow and deep waters, respectively). Moreover, in deep waters, 5 to $9 \mathrm{~cm}$ hake were in better condition in 2002 than in 2003, whereas they were more abundant in 2002 than in 2003 (Table 4: 2862 ind. $\mathrm{km}^{-2}$ vs. 209 ind. $\mathrm{km}^{-2}$ ).

\section{DISCUSSION}

Feeding is an important factor that determines the relationships of organisms in marine communities and the transfer of energy between trophic levels. Knowledge of the diet composition of juvenile fishes and their adaptability to food resource fluctuations with size is of major importance, and allows us to better understand the fluctuations in fish recruitment and ultimately fisheries landings (Lloret \& Lleonart 2002, Salen-Picard et al. 2002). In the Gulf of Lions, we analysed the spatiotemporal variations in juvenile hake diet and looked for relationships with stable isotope signature, condition and abundance in order to propose some hypotheses concerning fluctuations in the hake fisheries, which mainly rely on juveniles in the Mediterranean.

\section{Juvenile hake feeding}

Variations in the diet of juvenile hake in the Gulf of Lions were related to different factors: size (ontogeny), space (depth and zone) and time (year). At the beginning of their benthic life, juvenile hake $(<10 \mathrm{~cm}$ TL) fed mainly on small crustaceans (mysids, euphausiids, amphipods and shrimps). When growing (10 to $14 \mathrm{~cm}$ TL), they progressively consumed small benthic fish (gobiids) as well as crustaceans, and large juveniles (>15 cm TL) preyed principally on fishes (mostly pelagic species such as sardine and anchovy). The ontogenetic changes in the feeding of hake is described by numerous authors working in the Mediterranean (Papaconstantinou \& Caragitsou 1987, Bozzano et al. 1997, 2005, Cartes et al. 2004) and in the Atlantic (Guichet 1995, Du Buit 1996, Velasco \& Olaso 1998, Pinnegar et al. 2003), who all indicated that juveniles feed on small crustaceans and adults mostly on fish. Similar ontogenetic changes in feeding are also described for other hake species in the north Atlantic (Garrisson \& Link 2000). Bozzano et al. (1997) noted that the diet of hake smaller than $25 \mathrm{~cm}$ TL is more diverse than that of the adults. In analysing smaller size classes $(5 \mathrm{~cm}$ range instead of $10 \mathrm{~cm}$, as in most studies), we showed in the present study that the size range corresponding to the transition from crustacean to fish feeding in juvenile hake was restricted mainly to the 10 to $14 \mathrm{~cm}$ TL size class. An increase in the mobility of prey consumed by juvenile hake with increasing fish size, from relatively less-mobile crustaceans consumed by small juveniles to the highly mobile fish captured by large juveniles, is related to ontogenetic modifications in hake hearing (Lombarte \& Popper 1994) and vision (Mas-Riera 1991). However, as trawling captures were conducted only by day, the results obtained in this study only partially reflected the feeding patterns of juvenile hake. Bozzano et al. (2005) demonstrated that hake, particularly juveniles, are able to make diel vertical migrations that may reflect differences in prey availability. Juvenile hake vertically migrate up the water column at night, where they feed on fish and crustaceans in similar proportions, and stay closer to the bottom during the day, where their diet is dominated by crustaceans (Bozzano et al. 2005).

In the Gulf of Lions, the feeding of juvenile hake varied over the continental shelf. Depth was more important than zone when explaining variations in diet. Within the same size class, juveniles located in shallow waters (30 to $50 \mathrm{~m}$ ) fed mainly on fishes, whereas those located in deeper waters (70 to $150 \mathrm{~m}$ ) preyed mainly on crustaceans. This pattern was observed for the first time in the Mediterranean, because previous comparisons with depth were conducted between individuals from the continental shelf as a whole (Bozzano et al. 1997) and individuals from the slope (Cartes et al. 2004). However, this trend was also observed in the Atlantic (Velasco \& Olaso 1998) who demonstrated that, in the Cantabrian Sea, juvenile hake (17 cm TL) ingested more fish at depths $<100 \mathrm{~m}$ than in waters of 100 to $200 \mathrm{~m}$ depth (94 vs. $60 \%$ in volume, respectively). In the absence of data on prey abundance (suprabenthic crustaceans and small benthic fishes) with depth in the Gulf of Lions, it was not possible to relate variations in juvenile hake diet with feeding preference or prey availability, as was done for adult hake in the Celtic Sea (Pinnegar et al. 2003).

Juvenile hake feeding also varied with time. Studies on seasonal fluctuations in juvenile diet in the NW Mediterranean indicated maximum euphausiids consumption in spring, whereas mysids are the dominant crustaceans for the rest of the year and gobiids domi- 
nate in autumn (Bozzano et al. 1997). In the present study, samples were collected in spring (June) in 2 consecutive years (2002 and 2003). Diet of juvenile hake did not show interannual differences in shallow waters, but important interannual variations occurred in deep waters. The main prey consumed at 70 to $150 \mathrm{~m}$ depth in 2002 were mysids in waters close to the Rhone delta and euphausiids in the central and west parts of the Gulf of Lions. No euphausiids and few mysids were ingested in 2003; the dominant crustaceans were instead natantid decapods and amphipods. Dominance of euphausiids in the diet of juvenile hake in spring 2002 was in accordance with the pattern described by Bozzano et al. (1997), which could be related to reproductive aggregations of euphausiids during this season (Mauchline 1980). The shift to shrimps (Natantids) in 2003 might reflect the absence (euphausiids) or low abundance (mysids) of small crustaceans, which generally dominate the diet of small juvenile hake (Bozzano et al. 1997, Cartes et al. 2004).

\section{$\mathrm{C}$ and $\mathrm{N}$ stable isotope ratios}

No relationship was found between $\mathrm{C}$ and $\mathrm{N}$ isotope ratios of muscle and the total length of juvenile hake in the size range of individuals studied (5 to $19 \mathrm{~cm}$ TL) in 2002 and 2003. A number of studies demonstrated a positive correlation between fish length and $\delta^{15} \mathrm{~N}$ in muscle, because nitrogen stable isotope ratio reflects the trophic level of an organism, which generally increases with size (De Niro \& Epstein 1981, Minagawa \& Wada 1984, Vander Zanden \& Rasmussen 2001). Positive relationships between $\delta^{15} \mathrm{~N}$ and $\delta^{13} \mathrm{C}$ and fish length were observed for hake in the Gulf of Castellammare (Badalamenti et al. 2002) and Bay of Biscay (Le Loc'h \& Hily 2005), for a larger size range of individuals (12 to 55 and 9 to $47 \mathrm{~cm} \mathrm{TL}$, respectively) than that used in the present study. The 9 to $15 \mathrm{~cm}$ juvenile hake in the Bay of Biscay had higher $\delta^{15} \mathrm{~N}$ and lower $\delta^{13} \mathrm{C}$ values than the 10 to $14 \mathrm{~cm}$ juveniles analysed in the Gulf of Lions $\left(\delta^{15} \mathrm{~N}_{\text {Biscay }}=11.84 \%\right.$ vs. $\delta^{15} \mathrm{~N}_{\text {Lions }}=9.19 \% ; \delta^{13} \mathrm{C}_{\text {Biscay }}=-18.42 \%$ vs. $\delta^{13} \mathrm{C}_{\text {Lions }}=$ $-17.83 \%$ ), which might indicate differences in feeding behaviour or in isotope signatures of organic sources at the base of the food chains (i.e. phytoplankton).

Variability in stable isotope signatures of juvenile hake in the Gulf of Lions was only related to their spatial location, in particular to depth. In the size class 10 to $14 \mathrm{~cm} \mathrm{TL}, \delta^{15} \mathrm{~N}$ was higher in shallow (30 to $50 \mathrm{~m}$ ) than in deep waters (70 to $150 \mathrm{~m}$ ), and this pattern was more pronounced in 2002 than in 2003. The higher $\delta^{15} \mathrm{~N}$ and $\delta^{13} \mathrm{C}$ values in juvenile hake in shallow waters could be related to the higher consumption of fishes observed in this depth range, indicating a slightly higher trophic level of juvenile hake at depths $<50 \mathrm{~m}$. The absence of a correlation between the $\mathrm{N}$ isotopic ratio and \%IRI of fish at an individual level could be related to the different time scale at which stomach contents and stable isotopes reflect feeding. Stomach contents could be viewed as snap-shots, indicating which prey the fish had ingested a few minutes to hours before sampling. In contrast, stable isotope values in muscle reflect all the food types assimilated by the fish over the several months that precede sampling (Hesslein et al. 1993, MacAvoy et al. 2001). Differences in isotope signatures among individuals located in shallow and deep waters, observed in both years, suggested that juvenile hake were sedentary enough (for at least a few months) to exhibit different $\delta^{15} \mathrm{~N}$ and $\delta^{13} \mathrm{C}$ values. If juvenile hake movements were rapid and general, similar stable isotope signatures should be expected for individuals all over the Gulf of Lions. Our results showed that juvenile hake are probably less plastic and mobile at a small spatial scale than suggested by large-scale studies (Bozzano et al. 1997).

Hake are known to be opportunistic predators (Du Buit 1996, Bozzano et al. 1997, Velasco \& Olaso 1998), which implies the need to analyse a large number of individuals in order to obtain a representative view of the diet of a size class or local population. However, the spatial variability of $\delta^{15} \mathrm{~N}$ in juvenile hake, attributed here to diet composition, could also be the result of spatial differences in isotope signatures of organic sources at the base of food chains (Jennings \& Warr 2003). In that case, differences in $\delta^{15} \mathrm{~N}$ of hake observed with depth would not reflect trophic level variations but rather differences in the $\delta^{15} \mathrm{~N}$ of the food web baseline. Further analyses of the isotopic composition of the various components of the trophic web in which hake is embedded in the Gulf of Lions would allow a determination of the food web structure and subsequent distinction between the 2 hypotheses. The slightly lower $\mathrm{C}$ and $\mathrm{N}$ isotope ratios observed in juvenile hake sampled in Mediterranean waters close to the Rhone delta could reflect some influence from terrestrial organic carbon carried to the sea by the river on the trophic webs of fishes living close to the river mouth. Terrestrial organic matter has a lower $\delta^{13} \mathrm{C}$ content than marine organic matter, and can play an important role in marine productivity when incorporated into coastal marine trophic webs, as shown for the common sole (Darnaude et al. 2004).

\section{Juvenile hake condition}

Condition in fish is an important factor because it influences growth, reproduction and survival (Lambert \& Dutil 1997, Shulman \& Love 1999). Lloret et al. (2002) 
demonstrated that Fulton's condition factor in hake from the NW Mediterranean varied with length, year and depth. In spite of considerable interannual fluctuations, the mean condition factor of hake is higher in shallow than in deep habitats, and higher in the Gulf of Lions than in the Catalan Sea (Lloret et al. 2002). Lloret et al. (2002) related the condition factor of the fish analysed to the quality of the habitat, production being higher in shallow waters and in the northern part of the area studied. In our study, the relative condition factor of juvenile hake in the Gulf of Lions varied with depth and year. In 2003, juvenile hake located in deep waters had a lower condition factor than those living in shallow waters, whereas no difference with depth was observed in 2002. The main difference in the feeding of juveniles in deep waters between years was a diet composed mainly of mysids and euphausiids in 2002 and of natantids in 2003. This result might suggest that shrimps provided a less energetic source of food than small crustaceans (mysids and euphausiids) or, more likely, that more energy was spent on preying on these larger, more mobile organisms. The lack of differentiation in condition factor with depth in 2002 suggested that small crustaceans, the main prey in deep waters, were as energetically nutritious for juvenile hake as fishes, the main prey in shallow waters.

The study by Lloret et al. (2002) indicated that interannual variations in fish condition factor may be linked to environmental factors, intra- and interspecific competition and food supply. The present study indicated that there was no density effect on condition, because we observed similar condition indices among zones concurrent with differences in abundance, and vice versa. Finally, fluctuations in abundance of mysids and euphausiids might influence condition, growth and survival of juvenile hake in the Gulf of Lions.

\section{Juvenile hake abundance}

In the NW Mediterranean, hake recruitment occurs all year round-with peaks at different seasons depending on the geographic area-and exhibits large interannual fluctuations (Lloret \& Lleonart 2002, Maynou et al. 2003, Goñi et al. 2004). In the Gulf of Lions, the main peak in recruitment of juvenile hake occurs during spring (Recasens et al. 1998). On the Catalan coast, the principal nursery areas are found between 60 and $160 \mathrm{~m}$ and a positive relationship is observed between juvenile hake and euphausiids abundances; however, main peaks in juvenile hake and euphausiids abundance do not overlap (Maynou et al. 2003). Maynou et al. (2003) hypothesise that enhanced benthic food supply, principally the supply of euphausiids and mysids, may enhance juvenile hake survival in the nursery area. In the Gulf of Lions, the density of juvenile hake was higher at 70 to $150 \mathrm{~m}$ depth than in shallower waters, confirming the importance of this depth range as a potential nursery habitat for hake recruitment.

Juvenile density was significantly lower in 2003 than in 2002, and the between-year difference was much greater for the smallest juveniles (5 to $9 \mathrm{~cm}$ TL, which consumed small crustaceans) than for the largest ones (15 to $19 \mathrm{~cm} \mathrm{TL}$, which preyed on fishes). Diet analysis showed that no euphausiids and few mysids were found in the stomach contents of juvenile hake located in deep waters in 2003, and the condition factor of these juveniles was lower than for those of the previous year, which had consumed large quantities of these small crustaceans. Thus, these results validate the hypothesis of Maynou et al. (2003), which indicated that juvenile hake survival in nursery areas is enhanced with the availability of an adequate food supply (in this study: euphausiids and mysids). Different environmental factors such as hydrographic parameters, wind mixing, and primary productivity influence hake recruitment at large spatial scales in the Mediterranean, which largely influences larval stages (Lloret et al. 2001, Olivar et al. 2003). However, fluctuations in abundance of the small crustaceans (euphausiids and mysids), which are the preferred prey of the smallest juvenile hake could affect their growth and survival in nursery areas after benthic settlement, and eventually influence the landings of hake fisheries in the Mediterranean.

In conclusion, the present study showed that the transition from a crustacean-based diet to ichthyophagy occurred in medium-sized juvenile hake (10 to $14 \mathrm{~cm} \mathrm{TL}$ ). Depth, not zone, appeared to be a major geographic factor affecting the trophic relationships of these juvenile hake, and thus their condition and abundance. Juvenile hake preyed mainly on fishes when located in shallow waters, and on small crustaceans in deep waters. Difference in stable isotope signatures, with higher $\delta^{15} \mathrm{~N}$ and $\delta^{13} \mathrm{C}$ values in shallow water juvenile hake, suggested that migration between depth ranges was limited at that size. No interannual variation in diet was observed in juvenile hake located in shallow waters, but this was not true for deep water individuals. The relative condition of juveniles in deep waters was higher in 2002 (when they fed on mysids and euphausiids) than in 2003 (when they preyed on natantid shrimps). Because juvenile hake abundance was lower in 2003 than 2002, particularly in deep waters, we hypothesised that enhanced survival after benthic settlement could be partly related to the availability of an adequate food supply. 
Acknowledgements. Many thanks are expressed to the crew of RV 'L'Europe' for their most valuable help during the MEDITS surveys, and to C. Scrimgeour (Scottish Crop Research Institute) for isotope analysis. This study was funded by the IFREMER MEDICIS programme, the regional LanguedocRoussillon programme SYSCOLAG, and the National Programme on Coastal Ecology (PNEC). We acknowledge the 4 reviewers whose comments and suggestions improved this manuscript.

\section{LITERATURE CITED}

Abella A, Caddy JF, Serena F (1997) Declining natural mortality with age and fisheries on juveniles: a Mediterranean demersal fishery yield paradigm illustrated for Merluccius merluccius. Aquat Living Resour 10:257-269

Aldebert Y, Recascens L, Lleonart J (1993) Analysis of gear interactions in a hake fishery: the case of the Gulf of Lions (NW Mediterranean). Sci Mar 57:207-217

Badalamenti F, D'Anna G, Pinnegar JK, Polunin NVC (2002) Size-related trophodynamic changes in three target fish species recovering from intensive trawling. Mar Biol 141: 561-570

Bozzano A, Recasens L, Sartor P (1997) Diet of the European hake Merluccius merluccius (Pisces: Merluciidae) in the Western Mediterranean (Gulf of Lions). Sci Mar 61:1-8

Bozzano A, Sardà F, Ríos J (2005) Vertical distribution and feeding patterns of the juvenile European hake, Merluccius merluccius in the NW Mediterranean. Fish Res 73: 29-36

Cartes JE, Rey J, Lloris D, Gil de Sola L (2004) Influence of environmental variables on the feeding and diet of European hake (Merluccius merluccius) on the Mediterranean coasts. J Mar Biol Assoc UK 84:831-835

Cochran WG (1977) Sampling techniques, 3rd edn. In: Bradley RA, Hunter JS, Kendall DG, Watson GS (eds) Wiley series in probability and mathematical statistics. Wiley Interscience, New York

Darnaude AM, Salen-Picard C, Harmelin-Vivien ML (2004) Depth variation in terrestrial particulate organic matter exploitation by marine coastal benthic communities off the Rhone River delta (NW Mediterranean). Mar Ecol Prog Ser 275:47-57

De Niro MJ, Epstein S (1978) Influence of diet on the distribution of carbon isotopes in animals. Geochim Cosmochim Acta 42:495-506

De Niro MJ, Epstein S (1981) Influence of diet on the distribution of nitrogen isotopes in animals. Geochim Cosmochim Acta 45:341-351

Du Buit MH (1996) Diet of hake (Merluccius merluccius) in the Celtic Sea. Fish Res 28:381-394

Garrison LP, Link JS (2000) Diets of five hake species in the northeast United States continental shelf ecosystem. Mar Ecol Prog Ser 204:243-255

Goñi R, Adlerstein S, Alvarez F, Garcia M, Sánchez P, Sbrana M, Maynou F, Viva C (2004) Recruitment indices of European hake, Merluccius merluccius (Linnaeus 1758), in the Northwest Mediterranean based on landings from bottom-trawl multispecies fisheries. ICES J Mar Sci 61: 760-773

Guichet R (1995) The diet of European hake (Merluccius merluccius) in the northern part of the Bay of Biscay. ICES J Mar Sci 52:21-31

Hesslein RH, Hallard KA, Ramlal P (1993) Replacement of sulfur, carbon, and nitrogen in tissue of growing broad whitefish (Coregonus nasus) in response to a change in diet traced by $\delta^{34} \mathrm{~S}, \delta^{13} \mathrm{C}$ and $\delta^{15} \mathrm{~N}$. Can J Fish Aquat Sci 50:2071-2076

Hyslop EJ (1980) Stomach content analysis - a review of methods and their application. J Fish Biol 17:411-429

Jennings S, Warr KJ (2003) Environmental correlates of large-scale spatial variation in the $\delta^{15} \mathrm{~N}$ of marine animals. Mar Biol 142:1131-1140

Lambert Y, Dutil JD (1997) Can simple condition indices be used to monitor and quantify seasonal changes in the energy reserves of Atlantic cod (Gadus morhua)? Can J Fish Aquat Sci 54 (Suppl 1):104-112

Le Cren ED (1951) The length-weight relationship and seasonal cycle in gonad weight and condition in the perch (Perca fluviatilis). J Anim Ecol 20:201-219

Le Loc'h F, Hily C (2005) Stable carbon and nitrogen isotope analysis of Nephrops norvegicus/Merluccius merluccius fishing grounds in the Bay of Biscay (Northeast Atlantic). Can J Fish Aquat Sci 62:123-132

Lloret J, Lleonart J (2002) Recruitment dynamics of eight fishery species in the northwestern Mediterranean Sea. Sci Mar 66:77-82

Lloret J, Lleonart J, Solé I, Fromentin JM (2001) Fluctuations of landings and environmental conditions in the northwestern Mediterranean Sea. Fish Oceanogr 10:33-50

Lloret J, Gil de Sola L, Souplet A, Galzin R (2002) Effects of large-scale habitat variability on condition of demersal exploited fish in the north-western Mediterranean. ICES J Mar Sci 59:1215-1227

Lombarte A, Popper AN (1994) Quantitative analysis of postembrionic hair cell addition in the otolithic endorgans of the inner ear of the european hake, Merluccius merluccius (Gadiformes, Teleostei). J Comp Neurol 345: $419-428$

MacAvoy SE, Macko SA, Garman GC (2001) Isotopic turnover in aquatic predators: quantifying the exploitation of migratory prey. Can J Fish Aquat Sci 58:923-932

Mas-Riera J (1991) Changes during growth in the retinal structure of three hake species, Merluccius spp. (Teleostei: Gadiformes), in relation to their depth distribution and feeding. J Exp Mar Biol Ecol 152:91-104

Mauchline J (1980) The biology of mysids and euphausiids. Adv Mar Biol 18:1-681

Maynou F, Lleonart J, Cartes JE (2003) Seasonal and spatial variability of hake (Merluccius merluccius L.) recruitment in the NW Mediterranean. Fish Res 60:65-78

Minagawa M, Wada E (1984) Stepwise enrichment of ${ }^{15} \mathrm{~N}$ along food chains: further evidence and the relation between $\delta^{15} \mathrm{~N}$ and animal age. Geochim Cosmochim Acta 48: $1135-1140$

Olivar MP, Quílez G, Emelianov M (2003) Spatial and temporal distribution and abundance of European hake, Merluccius merluccius, eggs and larvae in the Catalan coast (NW Mediterranean). Fish Res 60:321-331

Orsi-Relini L, Papaconstantinou C, Jukic-Peladic S, Souplet A, Gil de Sola L, Piccinetti C, Kavadas S, Rossi M (2002) Distribution of the Mediterranean hake populations (Merluccius merluccius smiridus Rafinesque, 1810) (Osteichthyes: Gadiformes) based on six years monitoring by trawl surveys: some implications for management. Sci Mar 66 (Suppl 2):21-38

Papaconstantinou C, Caragitsou E (1987) The food of hake (Merluccius merluccius) in Greek Seas. Vie Milieu 37: 77-83

Pinkas L, Oliphant MS, Iverson ILK (1971) Food habits of albacore, bluefin tuna and bonito in Californian waters. Fish Bull 152:1-105 
Pinnegar JK, Polunin NVC (1999) Differential fractionation of $\delta^{13} \mathrm{C}$ and $\delta^{15} \mathrm{~N}$ among fish: implications for the study of trophic interactions. Funct Ecol 13:225-231

Pinnegar JK, Trenkel VM, Tidd AN, Dawson WA, Du Buit MH (2003) Does diet in Celtic Sea fishes reflect prey availability? J Fish Biol A 63:197-212

Recasens L, Lombarte A, Morales-Nin B, Torres GJ (1998) Spatiotemporal variations in the population structure of the European hake in the northwestern Mediterranean. J Fish Biol 53:387-401

Salen-Picard C, Darnaude AM, Arlhac D, Harmelin-Vivien ML (2002) Fluctuations of macrobenthic populations: a

Editorial responsibility: Konstantinos Stergiou (Contributing Editor), Thessaloniki, Greece link between climate-driven river runoff and sole fishery yields in the Gulf of Lions. Oecologia 133:380-388

Shulman GE, Love RM (1999) The biochemical ecology of marine fishes. In: Southward AJ, Tayler PA, Young CM (eds) Advances in marine ecology, Vol 36. Academic Press, London

Vander Zanden MJ, Rasmussen JB (2001) Variation in $\delta^{15} \mathrm{~N}$ and $\delta^{13} \mathrm{C}$ trophic fractionation: implications for aquatic food web studies. Limnol Oceanogr 46:2061-2066

Velasco F, Olaso I (1998) European hake Merluccius merluccius (L., 1758) feeding in the Cantabrian Sea: seasonal, bathymetric and length variations. Fish Res 38:33-44

Submitted: December 1, 2005; Accepted: September 21, 2006 Proofs received from author(s): April 6, 2007 